\title{
Impact of educational intervention on knowledge regarding safe handling of cytotoxic drugs among the nursing personnel working in BPKIHS
}

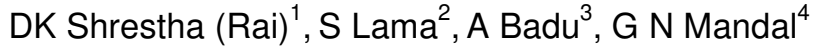 \\ Department of Maternal Health Nursing ${ }^{1}$, Department of Psychiatric Nursing ${ }^{2}$, Department of Community \\ Health Nursing ${ }^{3}$, Department of Medical Surgical Nursing College of Nursing ${ }^{4}$ \\ B.P. Koirala Institute of Health Sciences, Dharan, Nepal
}

\begin{abstract}
Introduction: Cytotoxic drugs are toxic compounds and are known to have carcinogenic, mutagenic and/or teratogenic potential. It is also considered as hazardous drugs. With direct contact they may cause irritation to the skin, eyes, and mucous membranes, and ulceration and necrosis of tissue. Safe handling refers to the process in which health care workers adhere to evidence-based practices (EBP) set forth by national organizations that have been designed to eliminate or significantly reduce occupational exposure. The key to safe handling is to protect the health care worker throughout the three phases of contact with the hazardous drugs. These phases are drug preparation, administration and disposal. Objective: To assess the effectiveness of education in enhancing the knowledge regarding safe handling of cytotoxic drugs among nursing personnel working at BPKIHS. Methods: Fifty nurses were taken as sample from selected ward of BPKIHS. One group pretest post test design was used by using population enumeration methods. Results: The overall mean score of knowledge on safe handling cytotoxic drugs of the respondents were 35.3 in the pre-test which increased to 83.7 in the post-test after an educational intervention. The difference was significant $(p<0.001)$. Conclusion: Thus, the study's findings highlighted that there was a significant improvement in knowledge of the staffs after educational intervention. The educational intervention was very effective to improve the knowledge of the staffs.
\end{abstract}

Key words: Cytotoxic drugs, educational intervention, knowledge, nursing personnel, safe handling

\footnotetext{
Address of correspondence

Dev Kumari Shrestha (Rai)

Department of Maternal Health Nursing

E-mail: devkumarirai@gmail.com
} 


\section{Introduction}

Cytotoxic drugs are toxic to cancer cells. They kill cancer cells, or stop them from multiplying. Different cytotoxic drugs do this in different ways. However, they all tend to work by interfering with some aspect of how the cells divide and multiply. ${ }^{1}$ Cytotoxic drugs are not only harmful for human tissue but also present specific risks for health care personnel, as they are known to be mutagenic, carcinogenic and teratogenic, warranting safe handling. ${ }^{2-4}$ The primary routes of exposure during the preparation and administration phases are through the inhalation of aerosolized drug or by direct skin contact. ${ }^{5}$ Nurse is the key person to care for cancer patient, thus, nurses with specialized knowledge and skills therefore play a major role in ensuring safe and competent administration of cytotoxic drugs and care of people receiving these treatments. The toxicity of cytotoxic drugs dictates that the exposure of health-care personnel to these drugs should be minimized. ${ }^{6}$ Nurses who administer chemotherapy can be exposed to aerosols of drugs generated during administration. Body fluids of patients receiving hazardous drugs are a potential source of exposure. Gloves and gowns are recommended to protect nurses against splash contamination during drug administration and handling patient wastes. It is time for nurses to take their own occupational safety as seriously as the safety of the patients under their care. This study was conducted to assess the effectiveness of education in enhancing the knowledge regarding safe handling of cytotoxic drugs among nursing personnel working at BPKIHS.

\section{Methods}

This is hospital based one group pre-test, post-test study conducted in 2010 in selected ward of B.P. Koirala Institute of Health Sciences (BPKIHS) where chemotherapy drugs were handled by using the universal sampling technique. Sample size was 50. A semi structure pretested closed and open ended questionnaire was developed.

Ethical clearance was obtained from IERB of BPKIHS included in acknowledgement. The ward incharges where cytotoxic drugs are used, i.e. medical, surgical, pediatric and gynaecological were informed about pretesting and intervention time and venue. The data was collected by investigator herself by administering questionnaire. The subjects were divided in to two groups $(24+26)$ according to feasibility of wards. Verbal consent was obtained from each participant.

Educational package was developed according to the need identified from the pretest and available literatures. Educational intervention was conducted after the pre-test. It was one hour educational intervention and 
LCD media player was used as teaching learning resources. Post test data was collected after four week of the intervention from the participants who participated in pre test and the intervention program.

The collected data was analyzed using descriptive and inferential statistics. Descriptive statistics was used to report the findings of pre-test and post-test knowledge. Knowledge score of the participants between the pre-test and post-test were compared by using Mc Nemar Chi-square test and Wilcoxon Sign Rank test and paired t test was used to find the overall significance of the educational intervention program. SPSS13 program was used to analyze the data.

\section{Results}

Demographic characteristics of the respondants is given in table 1.

Table 1: Demographic variable of respondents $(n=50)$

\begin{tabular}{|c|l|l|}
\hline Name of the colleges where the nurses were trained & \multicolumn{1}{|c|}{ No. } & \multicolumn{1}{|c|}{$\%$} \\
\hline TU (Trivuban University)/Bir Hopital & 18 & 36.0 \\
\hline $\begin{array}{l}\text { PU (Purwanchal University)/CTEVT (Center of technical education } \\
\text { and vocational training) }\end{array}$ & 28 & 56.0 \\
\hline BPKIHS (B.P.Koirala Institute of Health science) & 4 & 8.0 \\
\hline Department & \multicolumn{2}{l|}{} \\
\hline Medical & 17 & 34.0 \\
\hline Surgical & 22 & 44.0 \\
\hline Gynae & 5 & 10.0 \\
\hline Pediatric & 6 & 12.0 \\
\hline Total & 50 & 100.0 \\
\hline Year of experiences & \multicolumn{2}{|l}{} \\
\hline$<5$ years & 31 & 62.0 \\
\hline $5-10$ years & 11 & 22.0 \\
\hline $10-15$ years & 2 & 4.0 \\
\hline$>15$ years & 6 & 12.0 \\
\hline Total & 50 & 100.0 \\
\hline Age Group & 24 & 48.0 \\
\hline$<25$ & \multicolumn{2}{|l}{} \\
\hline
\end{tabular}




\begin{tabular}{|l|l|l|}
\hline $25-30$ & 17 & 34.0 \\
\hline $30-35$ & 2 & 4.0 \\
\hline $35-40$ & 1 & 2.0 \\
\hline$>40$ & 6 & 12.0 \\
\hline Total & 50 & 100.0 \\
\hline Educational Level & & \\
\hline ANM (Auxillary nurse midwife) & 10 & 20.0 \\
\hline CN (Ceritificate nursing) & 37 & 74.0 \\
\hline BN(Bachelor nursing) & 3 & 6.0 \\
\hline Total & 50 & 100.0 \\
\hline
\end{tabular}

Knowledge of the respondents regarding cytotoxic drugs is given in table 2 .

Table 2: Knowledge of respondents regarding cytotoxic drugs (CD) $(n=50)$

\begin{tabular}{|c|c|c|c|c|c|c|}
\hline \multirow[t]{2}{*}{ Knowledge of CD } & \multicolumn{2}{|c|}{$\begin{array}{l}\text { Pretest } \\
(n=50)\end{array}$} & \multicolumn{2}{|c|}{$\begin{array}{l}\text { Post test } \\
(n=50)\end{array}$} & \multirow{2}{*}{$\begin{array}{c}\text { Differences } \\
(\%)\end{array}$} & \multirow[t]{2}{*}{$P=$ value } \\
\hline & Yes & $\%$ & Yes & $\%$ & & \\
\hline Heard about CD & 44 & 88.0 & 49 & 98.0 & 10.0 & 0.139 \\
\hline Familiar with CD & 26 & 52.0 & 46 & 92.0 & 40.0 & 0.001 \\
\hline CD are toxic & 27 & 54.0 & 50 & 100.0 & 46.0 & 0.001 \\
\hline CD kill cancer cell & 33 & 66.0 & 50 & 100.0 & 44.0 & 0.001 \\
\hline Different drug work differently & 21 & 42.0 & 50 & 100.0 & 58.0 & 0.001 \\
\hline $\begin{array}{l}\text { Some work by affect genetic } \\
\text { materials }\end{array}$ & 12 & 24.0 & 49 & 98.0 & 74.0 & 0.001 \\
\hline $\begin{array}{l}\text { Most normal cell do not divide and } \\
\text { multiply very often }\end{array}$ & 8 & 16.0 & 46 & 92.0 & 76.0 & 0.001 \\
\hline Two or more $C D$ are used together & 21 & 42.0 & 46 & 92.0 & 50.0 & 0.001 \\
\hline $\begin{array}{l}\text { More than } 30 \text { different CD are } \\
\text { available }\end{array}$ & 10 & 20.0 & 49 & 98.0 & 78.0 & 0.001 \\
\hline $\begin{array}{l}\text { Chosen on type and stage of the } \\
\text { most research trails }\end{array}$ & 19 & 38.0 & 48 & 96.0 & 58.0 & 0.001 \\
\hline $\begin{array}{l}\text { Doctor advice best treatment } \\
\text { according to type }\end{array}$ & 21 & 42.0 & 49 & 98.0 & 56.0 & 0.001 \\
\hline
\end{tabular}




\begin{tabular}{|l|l|l|l|l|l|l|}
\hline $\begin{array}{l}\text { CD are best for rapid dividing and } \\
\text { multiplying cell }\end{array}$ & 25 & 50.0 & 50 & 100.0 & 50.0 & 0.001 \\
\hline $\begin{array}{l}\text { Some normal cell divide and } \\
\text { multiply quite rapidly }\end{array}$ & 12 & 24.0 & 48 & 96.0 & 72.0 & 0.001 \\
\hline
\end{tabular}

Knowledge of the respondents regarding administration of injectable cytotoxic drugs is given in table 3.

Table 3: Knowledge of administration of injectable cytotoxic drugs(CD) $(n=50)$

\begin{tabular}{|l|l|l|l|l|l|l|}
\hline \multirow{2}{*}{ Injectable adminstration of CD } & \multicolumn{2}{|c|}{$\begin{array}{c}\text { Pre-test } \\
(\mathbf{n = 5 0})\end{array}$} & \multicolumn{2}{|c|}{$\begin{array}{c}\text { Post-test } \\
(\mathbf{n = 5 0})\end{array}$} & Differences & P=value \\
\cline { 2 - 8 } & Yes & $\%$ & Yes & $\%$ & & \\
\hline Preparation of injectable CD & 13 & 26.0 & 44 & 88.0 & 62.0 & 0.001 \\
\hline Use luer lock fittings on needles & 9 & 18.0 & 47 & 94.0 & 78.0 & 0.001 \\
\hline $\begin{array}{l}\text { Use appropriate receptacle } \\
\text { container to carry syringes }\end{array}$ & 10 & 20.0 & 46 & 92.0 & 72.0 & 0.001 \\
\hline Prime I/Vdrip start first without drugs & 12 & 24.0 & 47 & 92.0 & 68.0 & 0.001 \\
\hline Connect iv bag at waist level & 7 & 14.0 & 45 & 90.0 & 76.0 & 0.001 \\
\hline CD labeling to all container & 16 & 32.0 & 48 & 96.0 & 64.0 & 0.001 \\
\hline Use disposable gauze squares & 12 & 24.0 & 47 & 94.0 & 70.0 & 0.001 \\
\hline Use plastic backed absorbent & 11 & 22.0 & 46 & 92.0 & 70.0 & 0.001 \\
\hline $\begin{array}{l}\text { Return air containing syringe to } \\
\text { Pharmacy/suppliers }\end{array}$ & 4 & 8.0 & 45 & 90.0 & 82.0 & 0.001 \\
\hline Do not recap needles & 12 & 24.0 & 49 & 98.0 & 74.0 & 0.001 \\
\hline Dispose of empty IV bags or flasks & 7 & 14.0 & 45 & 90.0 & 76.0 & 0.001 \\
\hline
\end{tabular}

Table 4 Knowledge of conditions thay may recruit in inhalation of air born contaminants during parenteral administration $(n=50)$

\begin{tabular}{|l|c|c|c|c|l|l|}
\hline $\begin{array}{c}\text { Condition to inhale air born } \\
\text { contaminants }\end{array}$ & \multicolumn{2}{|c|}{$\begin{array}{c}\text { Pretest } \\
(\mathbf{n = 5 0}\end{array}$} & \multicolumn{2}{|c|}{$\begin{array}{c}\text { Post test } \\
(\mathbf{n = 5 0})\end{array}$} & $\begin{array}{c}\text { differences } \\
(\%)\end{array}$ & \multirow{2}{*}{ P=value } \\
\cline { 2 - 6 } & Yes & $\%$ & Yes & $\%$ & & \\
\hline Drugs filled syringe & 15 & 30.0 & 48 & 96.0 & 66.0 & 0.001 \\
\hline Withdrawal of needles from iv & 17 & 34.0 & 50 & 100.0 & 66.0 & 0.001 \\
\hline
\end{tabular}




\begin{tabular}{|l|l|l|l|l|l|l|}
\hline Penetrating injury & 26 & 52.0 & 49 & 98.0 & 46.0 & 0.001 \\
\hline Splashes and leakages of & 28 & 56.0 & 50 & 100.0 & 44.0 & 0.001 \\
\hline Spills of CD & 25 & 50.0 & 49 & 98.0 & 48.0 & 0.001 \\
\hline
\end{tabular}

Table 5: Knowledge regarding uses of personal protective devices $(n=50)$

\begin{tabular}{|l|l|c|c|c|l|l|}
\hline \multicolumn{1}{|c|}{$\begin{array}{c}\text { Personal protective } \\
\text { devices }\end{array}$} & \multicolumn{2}{c|}{$\begin{array}{c}\text { Pretest } \\
(\mathbf{n}=\mathbf{5 0})\end{array}$} & \multicolumn{2}{c|}{$\begin{array}{c}\text { Post test } \\
(\mathbf{n}=\mathbf{5 0})\end{array}$} & $\begin{array}{c}\text { Differences } \\
\text { (\%) }\end{array}$ & P=value \\
\cline { 2 - 6 } & Yes & $\%$ & Yes & $\%$ & & \\
\hline Gown & 32 & 64.0 & 49 & 98.0 & 34.0 & 0.008 \\
\hline Gloves & 43 & 86.0 & 49 & 98.0 & 12.0 & 0.151 \\
\hline Eye glass & 34 & 68.0 & 49 & 98.0 & 30.0 & 0.001 \\
\hline Mask & 36 & 72.0 & 49 & 98.0 & 26.0 & 0.001 \\
\hline Boots & 21 & 42.0 & 49 & 98.0 & 56.0 & 0.001 \\
\hline Helmet & 15 & 30.0 & 47 & 94.0 & 64.0 & 0.001 \\
\hline
\end{tabular}

Table 5 shows the knowledge of the respondents regarding uses of personal protective devices.

Table 6: Knowledge regarding hazard of handling cytotoxic drugs (CD) $(n=50)$

\begin{tabular}{|l|l|l|l|l|l|l|}
\hline \multirow{2}{*}{ Hazard of using CD } & \multicolumn{2}{|c|}{$\begin{array}{c}\text { Pre-test } \\
(\mathbf{n = 5 0})\end{array}$} & \multicolumn{2}{|c|}{$\begin{array}{c}\text { Post-test } \\
(\mathbf{n = 5 0 )}\end{array}$} & $\begin{array}{c}\text { Differences } \\
\text { (\%) }\end{array}$ & \multirow{2}{*}{ P=value } \\
\cline { 2 - 6 } & Yes & $\%$ & Yes & $\%$ & & \\
\hline Knowledge of handling CD & 18 & 36.0 & 50 & 100.0 & 64.0 & 0.001 \\
\hline Direct irritant mucous, eyes skin & 24 & 48.0 & 50 & 100.0 & 52.0 & 0.001 \\
\hline $\begin{array}{l}\text { Spills on to cut skin surfaces may } \\
\text { affects }\end{array}$ & 16 & 32.0 & 50 & 100.0 & 68.0 & 0.001 \\
\hline $\begin{array}{l}\text { Dizzines, light headacheness, } \\
\text { nausea }\end{array}$ & 14 & 28.0 & 50 & 100.0 & 72.0 & 0.001 \\
\hline occupational effect & 13 & 26.0 & 50 & 100.0 & 74.0 & 0.001 \\
\hline $\begin{array}{l}\text { Small quantities of drug may affect } \\
\text { extended period }\end{array}$ & 7 & 14.0 & 50 & 100.0 & 86.0 & 0.001 \\
\hline $\begin{array}{l}\text { Cytogenic abnormalities, mutagenic, } \\
\text { teratonic effects }\end{array}$ & 10 & 20.0 & 50 & 100.0 & 80.0 & 0.001 \\
\hline Alteration to normal blood cell count & 13 & 26.0 & 50 & 100.0 & 74.0 & 0.001 \\
\hline Excretion of the drugs/metabolites & 6 & 12.0 & 50 & 100.0 & 88.0 & 0.001 \\
\hline Abdominal pain, hair loss, nasal & 12 & 24.0 & 50 & 100.0 & 76.0 & 0.001 \\
\hline
\end{tabular}




\begin{tabular}{|l|l|l|l|l|l|l|}
\hline Liver damage & 11 & 22.0 & 49 & 98.0 & 76.0 & 0.001 \\
\hline Fertility changes & 15 & 30.0 & 50 & 100.0 & 70.0 & 0.001 \\
\hline Fetal loss and malformations & 18 & 36.0 & 50 & 100.0 & 64.0 & 0.001 \\
\hline
\end{tabular}

Table 6 shows knowledges regarding Hazard of Handling CD.

Table 7: Knowledge regarding sources of risk transmission $(n=50)$

\begin{tabular}{|l|l|l|l|l|l|l|}
\hline \multirow{2}{*}{$\begin{array}{c}\text { Sources of risk } \\
\text { transmission through }\end{array}$} & \multicolumn{2}{c|}{$\begin{array}{c}\text { Pretest } \\
\text { (n=50) }\end{array}$} & \multicolumn{2}{c|}{$\begin{array}{c}\text { Post test } \\
\text { (n=50) }\end{array}$} & Differences & P=value \\
\cline { 2 - 7 } & Yes & \% & Yes & $\%$ & (\%) & \\
\hline Skin contact & 12 & 24.0 & 48 & 96.0 & 72.0 & 0.001 \\
\hline Skin absorption & 28 & 56.0 & 50 & 100.0 & 44.0 & 0.001 \\
\hline Inhalation of drug particles & 28 & 56.0 & 50 & 100.0 & 44.0 & 0.001 \\
\hline Ingestion of drugs particles & 21 & 42.0 & 44 & 88.0 & 46.0 & 0.001 \\
\hline Needle stick injury & 24 & 48.0 & 28 & 56.0 & 8.0 & 0.151 \\
\hline
\end{tabular}

Table 7 shows that, knowledge of Ingestion of drugs particles. The difference respondents regarding sources of risk were markedly significant in regarding needle transmission through skin contact, skin stick injury, the difference was insignificant absorption, Inhalation of drug particles, i.e. $P=0.151$.

Table 8: Knowledge of common risk condition $(n=50)$

\begin{tabular}{|l|l|c|c|c|l|l|}
\hline \multirow{2}{*}{ Common risk condition } & \multicolumn{2}{|c|}{$\begin{array}{c}\text { Pretest } \\
(\mathbf{n = 5 0 )}\end{array}$} & \multicolumn{2}{c|}{$\begin{array}{c}\text { Post test } \\
(\mathbf{n = 5 0 )}\end{array}$} & $\begin{array}{c}\text { Differences } \\
\text { (\%) }\end{array}$ & \multirow{2}{*}{ P=value } \\
\cline { 2 - 6 } & Yes & $\%$ & Yes & $\%$ & & \\
\hline Drug preparation & 35 & 70.0 & 50 & 100.0 & 30.0 & 0.001 \\
\hline Drug administration & 31 & 62.0 & 50 & 100.0 & 38.0 & 0.001 \\
\hline Handling waste & 23 & 46.0 & 50 & 100.0 & 54.0 & 0.001 \\
\hline Transport and waste disposal & 29 & 58.0 & 50 & 100.0 & 42.0 & 0.001 \\
\hline Cytotoxic drug container & 30 & 60.0 & 50 & 100.0 & 40.0 & 0.001 \\
\hline Handling bed linen & 16 & 32.0 & 49 & 98.0 & 66.0 & 0.006 \\
\hline
\end{tabular}

Table 8 shows knowledge regarding conditions that the risk is most likely to occur. 
Table 9: Change in the percentage of responses after the educational intervention $(n=50)$

\begin{tabular}{|l|l|l|l|}
\hline Intervention & Mean & St. Deviation & P value \\
\hline Pretest & 35.3 & 16.8 & $<0.001$ \\
\hline Post test & 83.7 & 3.8 & \\
\hline
\end{tabular}

The overall mean score of knowledge on safe handling cytotoxic drugs of the respondents were 35.3 in the pre-test which incurred to 83.7 in the post-test after the educational intervention. The difference was found to be significant $(p<0.001)$.

\section{Discussion}

Knowledge of respondents regarding cytotoxic drugs significantly improved in post test. Knowledges about preparation and administration of injectable cytotoxic drugs also markedly increased in the post test.

Knowledges of conditions, that can lead to inhalation of contaminants during parenteral administration of cytotoxic drugs also increased in post test significantly.

Results showed that uses of personal protective devices, like gown, eye glass, mask, shoes, helmet, the differences significantly increased in post test. Our finding is comparable to another study which showed current patterns of use of personal protective equipment among oncology nurses while handling antineoplastic agents more than $94 \%$ reported usually wearing gloves during chemotherapy handling, which is similar to this study (98\%); $55 \%$ reported using laboratory coats. Use of face and respiratory protection was less than $6 \%$. Chemotherapy was reported to be prepared in laminar air flow hoods in $99 \%$ of work settings. ${ }^{10}$

Knowledges regarding hazard of handling cytotoxic drugs, has markedly increased in post test and the difference was significant and $p$ value $<0.5$. Study has shown that knowledge attitudes and beliefs of Cypriot nurses on their exposure to antineoplastic agents, majority of nurses were aware of the potential hazards with handling of chemotherapy, which is similar with this study in post test ${ }^{11}$.

Knowledges regarding sources of risk transmission through skin contact, skin absorption, inhalation and ingestion of drugs partiles the difference were highly significant in post but knowledge of needle stick injury was not significantly different.

Knowledges regarding condition that the risk is most likely to occur during drug preparation, and administration, handling waste, transport and waste disposal, cytotoxic drug container, and bed linen, the difference were markedly increased.

The mean score of knowledge on safe handling cytotoxic drugs of the respondents were 35.3 in the pre-test and 83.7 in the posttest. The difference was significant $(p<0.001)$. Another study concluded the mean score of the nurse' knowledge safe handling of 
chemotherapy was $79.43^{11}$ a finding on post test with this study.

A study has shown that knowledge, attitude and safe behavior of nurses handling cytotoxic drugs, the knowledge of the nurses concerning antineoplastics was unsatisfactory. ${ }^{9}$ Thus finding of this study was similar with this study in pretest.

Study revealed that The Influence of nurses' knowledge, attitudes, and health beliefs on their safe behavior with cytotoxic drugs, a gap was found between the nurses' knowledge and their actual behavior cytotoxic drugs and their use of protective measures. ${ }^{7}$ the finding was similar with this study related to pretest and post test it was highly significant..

\section{Conclusion}

Educational intervention on knowledge regarding Safe handing cytotoxic drugs is effective measures to prevent from hazards. It could be helpful to promote primary prevention by providing a safe environment for the employee by means of education, refreshment training regarding safety measures, clear policy, written guidelines and their enforcement.

\section{References}

1. Guidelines on handling cytotoxic drugs Trained personnel (accessed 11 Apr 2011) available from URL http://www.hse.gov.uk/press/2003/e03179
2. gosh.nhs.uk Safe handling of cytotoxic medication. Clinical guideline cytotoxic and cytostatic medication safe (accessed Feb 2011) available from URL www.hse.gov.uk/pubns/misc615.pdf.

3. Mahon SM et al. Safe handling practices of cytotoxic drugs: the results of a chapter survey. Oncol Nurs Forum. 1994;21(7):1157-1165.

4. Polovich M. Safe handling of hazardous drugs (accessed Feb 2011) Available www.nursingworld.org/MainMenuCategori es/ANAMarketplace/ANAPeriodicals/OJIN

5. Position Statement, Cancer Nurses Society of Australia Chemotherapy: July 2003. Review July 2006

6. Recommendations for the safe use of handling of cytotoxic drugs. (accessed Feb 2010) available at dohs.ors.od.nih.gov/pdf/

7. Ben-Ami S, Shaham J, Rabin S, Melzer A, Ribak $J$ et al. The influence of nurses' knowledge, attitudes, and health beliefs on their safe behavior with cytotoxic drugs in Israel. Cancer Nursing. 2001 Jun;24(3):192-200.

8. Crauste $M S$ environmental contamination with cytotoxic drugs in healthcare using positive air pressure isolators, 2005(accessed Feb 2010) available annhyg.oxfordjournals.org/content/49/7/6 19.full.pdf.

9. Turk M. et al. Knowledge, attitude and safe behaviour of nurses handling 
10. Cytotoxic drugs in Ege University Hospital. Asian Pac J Cancer Prev. 2004;5(2):164-8.

11. Susan M., Elaine L. ChemotherapyHandling Practices of Outpatient and Office-Based Oncology Nurses Oncology
Nursing Forum Oncology Nursing Society 2003; 30: 575-581.

12. Maro K. et al. Knowledge, attitudes and beliefs of Cypriot nurses on the handling of antineoplastic agents EJON, 2010; 14: 278-282. 